\title{
Proliferation and functional maturation of Sertoli cells, and their relevance to disorders of testis function in adulthood
}

\author{
Richard M. Sharpe, Chris McKinnell, Catrina Kivlin and Jane S. Fisher \\ MRC Human Reproductive Sciences Unit, Centre for Reproductive Biology, The Chancellor's Building, \\ University of Edinburgh, 49 Little France Crescent, Old Dalkeith Road, Edinburgh EH16 4SB, UK
}

\begin{abstract}
Disorders of testicular function may have their origins in fetal or early life as a result of abnormal development or proliferation of Sertoli cells. Failure of Sertoli cells to mature, with consequent inability to express functions capable of supporting spermatogenesis, is a prime example. In a similar way, failure of Sertoli cells to proliferate normally at the appropriate period in life will result in reduced production of spermatozoa in adulthood. This review focuses on the control of proliferation of Sertoli cells and functional maturation, and is motivated by concerns about 'testicular dysgenesis syndrome' in humans, a collection of common disorders (testicular germ-cell cancer, cryptorchidism, hypospadias and low sperm counts) which are hypothesized to have a common origin in fetal life and to reflect abnormal function of Sertoli (and Leydig) cells. The timing of proliferation of Sertoli cells in different species is reviewed, and the factors that govern the conversion of an immature, proliferating Sertoli cell to a mature, non-proliferating cell are discussed. Protein markers of maturity and immaturity of Sertoli cells in various species are reviewed and their usefulness in studies of human testicular pathology are discussed. These markers include anti-Mullerian hormone, aromatase, cytokeratin-18, GATA-1, laminin alpha5,

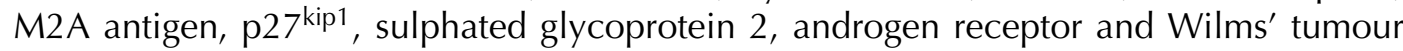
gene. A scheme is presented for characterization of Sertoli-cell only tubules in the adult testis according to whether or not there is inherent failure of maturation of Sertoli cells or in which the Sertoli cells have matured but there is absence, or acquired loss, of germ cells. Functional 'de-differentiation' of Sertoli cells is considered. It is concluded that there is considerable evidence to indicate that disorders of maturation of Sertoli cells may be a common underlying cause of human male reproductive disorders that manifest at various life stages. This recognition emphasizes the important role that animal models must play to enable identification of the mechanisms via which failure of proliferation and maturation of Sertoli cells can arise, as this failure probably occurs in fetal life.
\end{abstract}

The Sertoli cell plays a central role in development of a functional testis, and hence in the expression of a male phenotype. Sertoli cells are the first cells to differentiate recognizably in the indifferent fetal gonad, an event which enables seminiferous cord formation, prevention of germ-cell entry into meiosis and differentiation and function of the Leydig cells (Mackay, 2000). The secretions of the Leydig cells (testosterone, insulin-like factor 3) then play vital roles in downstream masculinization events and in descent of the testes into the scrotum (Hutson et al., 1997; Sharpe, 2001). The Sertoli cells also ensure regression of the Mullerian ducts via secretion of anti-Mullerian hormone $(\mathrm{AMH}$; Mackay, 2000; Josso et al., 2001). When these events

Email: r.sharpe@hrsu.mrc.ac.uk have occurred, and some time has passed, the role of the Sertoli cell switches during puberty to the support of spermatogenesis. Without the physical and metabolic support of the Sertoli cells, germ-cell differentiation, meiosis and transformation into spermatozoa would not occur (Sharpe, 1994). Moreover, the number of Sertoli cells will determine the number of germ cells that can be supported through spermatogenesis and hence will numerically determine the extent of sperm production (Orth et al., 1988; Sharpe, 1994, 1999), a factor with obvious bearing on fertility.

This brief 'job description' of the Sertoli cell emphasizes its two functionally separate roles, in the process of testis formation or sexual differentiation and in spermatogenesis. These events are separated in time and by function. Thus, the functions of the Sertoli cell expressed in adult life to support spermatogenesis are 
largely absent during fetal life (insofar as is known), and the converse is also true to some extent. The switch from 'fetal' to 'adult' Sertoli cell appears to occur during puberty and is termed 'maturation' or 'differentiation', and is likely to be a multi-step process. The term 'differentiation' applies because the Sertoli cells are terminally differentiating into their adult form, but as this term is also used to describe the morphological differentiation of the Sertoli cells in fetal life, the term 'functional maturation' will be used in this review. Maturation involves loss of proliferative ability, formation of inter-Sertoli cell tight junctions and expression of functions not present in immature Sertoli cells. Though functional maturation of Sertoli cells is temporally separate from Sertoli-cell development and function in fetal life, it is inevitable that what happens to the Sertoli cells during their 'fetal period' (which extends out into neonatal life) will to some extent predetermine their function or behaviour in adulthood. It is the connections between fetal and adult functions of the Sertoli cells and the consequences and manifestation of failure of proliferation or 'functional maturation' of Sertoli cells that are the focus of this review. As this is a broad area, reviews have been cited wherever possible to provide sources of more detailed information.

\section{Testicular dysgenesis syndrome}

The motivation for this review is the hypothesis that, in humans, testicular germ-cell cancer, cryptorchidism, hypospadias and some cases of low sperm counts form a syndrome of disorders, testicular dysgenesis syndrome (TDS), with a common origin in fetal life (Skakkebaek et al., 2001). These disorders are risk factors for each other and share several pregnancy-related risk factors and, from a cell biology point of view, a strong case can be made for their common origin (Sharpe and Skakkebaek, in press). It is proposed that TDS results from abnormal function of Sertoli and Leydig cells in fetal life with either immediate (testis descent, masculinization) or delayed (testis cancer, low sperm counts) consequences. Analysis of biopsies of the contralateral (tumour-free) testis in patients with testis cancer has revealed a high prevalence of abnormal focal features such as immature Sertoli cells, poorly formed seminiferous tubules and Sertoli cell-only (SCO) tubules (Hoei-Hanson et al., in press). Such analyses raise many questions. For example, what should be concluded when an SCO tubule is observed in the adult testis? Does it indicate that the Sertoli cells did not develop normally so that germ cells could not survive? Or is the function of the Sertoli cells normal, but the SCO has arisen because of an inherent problem with the germ cells or because of their postnatal loss (for example, due to infection, orchitis, trauma, irradiation, chemotherapy, heat exposure)? Again, considering the vital role that the number of Sertoli cells plays in determining sperm production or sperm counts in adulthood (see below), are there factors acting in fetal life that may affect proliferation of Sertoli cells at this time or alter the ability of Sertoli cells to proliferate postnatally? These issues are addressed in this review, which focuses on what is known about the factors that can influence the proliferation and functional maturation of Sertoli cells.

\section{Proliferation of Sertoli cells}

The number of Sertoli cells in the adult testis determines both testis size and daily sperm production. This relationship occurs because each Sertoli cell has a fixed capacity for the number of germ cells that it can support (Orth et al., 1988), though this capacity varies between species (Sharpe, 1994). Only immature Sertoli cells proliferate, so the final number of Sertoli cells is determined before adulthood. At face value, there appear to be fundamental differences between species as to when Sertoli cells proliferate, because in rodents all proliferation occurs in fetal and neonatal life, whereas in rhesus monkeys proliferation occurs predominantly in the peripubertal period (Fig. 1). However, as more data is obtained from more species, a consensus interpretation is now possible (see, for example, Plant and Marshall, 2001). This indicates that Sertoli cells proliferate during two periods of life, in fetal or neonatal life and in the peripubertal period in all species. In some species (for example rhesus monkeys), one period may be far more important than the other (Plant and Marshall, 2001), whereas in most species proliferation of Sertoli cells occurs in both periods, although the fetal or neonatal period is probably the more important (Fig. 1). Confusion has arisen because in species such as the rat, in which the neonatal period overlaps with the peripubertal period, it is difficult to discern the two periods of proliferation of Sertoli cells. In contrast, in humans, these periods are separated by a decade or more and in lower primates by periods of months (Fig. 1). Intermediate between the extremes of rodents and primates are species such as the bull and pig, in which there is a short gap (weeks) between the neonatal and peripubertal periods, but in which two corresponding peaks of proliferation of Sertoli cells can be discerned (De Franca et al., 2000).

Arguably, the most puzzling observation is why rhesus monkeys, but not humans or marmosets (or Cebus monkeys), exhibit such a low proliferation of Sertoli cells during the neonatal period. Another curious finding is that in normal marmoset monkeys, adult numbers of Sertoli cells are present by the end of the neonatal period, implying that peripubertal proliferation does not occur in this species (Fig. 1). However, it is clear that Sertoli cells can proliferate after the neonatal period in marmoset monkeys. In a study in which proliferation of Sertoli cells was inhibited by neonatal treatment with a GnRH antagonist (to suppress FSH concentrations), a reduction of about $35 \%$ in the number of Sertoli cells was evident at the end of the neonatal period. 


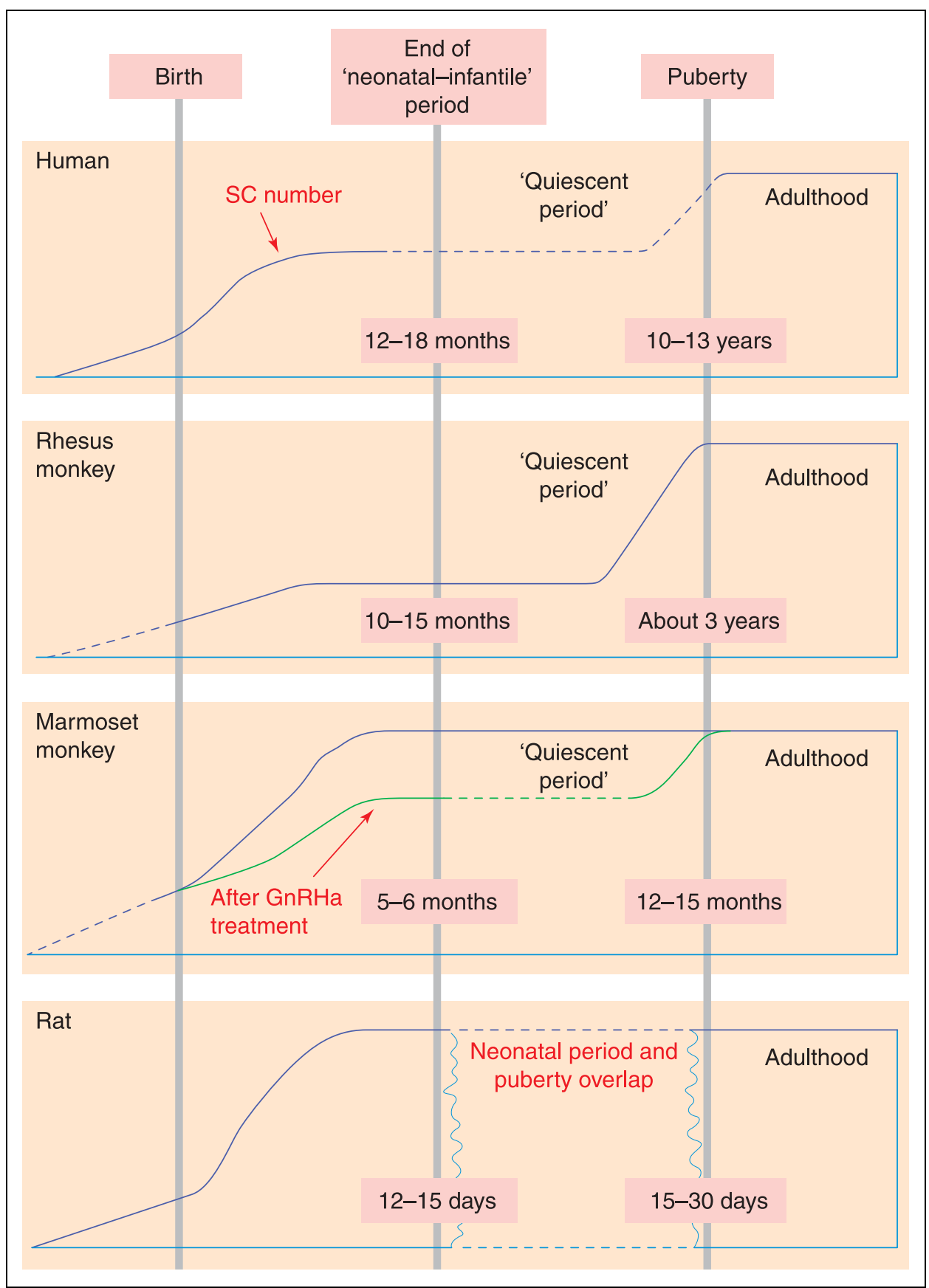

Fig. 1. Schematic diagram illustrating timing of proliferation of Sertoli cells (SC) in humans, rhesus and marmoset monkeys, and rats in relation to birth, the neonatal period and puberty. The dark blue line indicates the change in relative number of Sertoli cells for that species, based on reported data (references below); where there are data gaps, a dashed blue line is shown. Note that in rats, the end of the neonatal period and the onset of puberty overlap so that adult numbers of Sertoli cells are already present by the end of the 'neonatal' period. The green line shown in the panel for the marmoset indicates what happens to the number of Sertoli cells in animals that are treated from birth to the end of the neonatal period with a $\mathrm{GnRH}$ antagonist to suppress pituitary gonadotrophin secretion. This diagram is based mainly on data from: Cortes et al. (1987); Wang et al. (1989); Marshall and Plant (1996); Mann et al. (1997) and Sharpe et al. (2000). 
Table 1. Effect of various neonatal hormonal manipulations in rats on final number of Sertoli cells, testis mass and blood concentrations of inhibin B

Percentage of appropriate control

\begin{tabular}{|c|c|c|c|c|}
\hline \multirow[b]{2}{*}{ Neonatal treatment } & & \multirow[b]{2}{*}{ Reference(s) } \\
\hline & $\begin{array}{l}\text { Number of } \\
\text { Sertoli cells }\end{array}$ & Testis mass & $\begin{array}{l}\text { Blood concentration } \\
\text { of inhibin } \mathrm{B}^{\mathrm{a}}\end{array}$ & \\
\hline $\mathrm{GnRH}$ antagonist (suppression of FSH) & $45-52 \%$ & $46 \%$ & $63-79 \%$ & $\begin{array}{l}\text { Atanassova et al., } 1999 \\
\text { Sharpe et al., } 1999\end{array}$ \\
\hline Treatment with recombinant FSH & $149 \%$ & $124 \%$ & $\mathrm{~nm}$ & Meachem et al., 1996 \\
\hline Hemicastration (raises FSH concentrations) & $118 \%$ & $133 \%$ & $\mathrm{~nm}$ & Simorangkir et al., 1995 \\
\hline Hypothyroidism & $182-257 \%$ & $127-162 \%$ & $215 \%$ & $\begin{array}{l}\text { Hess et al., } 1993 \\
\text { Simorangkir et al., } 1995 \\
\text { Sharpe et al., } 1999\end{array}$ \\
\hline Hemicastration + hypothyroidism & $123 \%$ & $162 \%$ & $\mathrm{~nm}$ & Simorangkir et al., 1995 \\
\hline $\begin{array}{l}\text { Polychlorinated biphenyls } \\
\text { (induces mild hypothyroidism) }\end{array}$ & $132.6-139.4 \%$ & $114.8-116.5 \%$ & $\mathrm{~nm}$ & Kim, 2001 \\
\hline Hyperthyroidism & $50 \%$ & $52 \%$ & $\mathrm{~nm}$ & van Haaster et al., 1993 \\
\hline Diethylstilboestrol (suppresses FSH) & $64 \%$ & $49 \%$ & $31 \%$ & Atanassova et al., 1999 \\
\hline
\end{tabular}

${ }^{a}$ Note that FSH concentrations in adulthood usually show the converse change to that indicated for inhibin B. $\mathrm{nm}$ : not measured.

However, when comparably treated males were allowed to grow to adulthood they had restored normal numbers of Sertoli cells (Sharpe et al., 2000; Fig. 1); it is presumed that the compensatory proliferation occurred during the peripubertal period.

\section{Hormonal and other factors influencing final number of Sertoli cells}

As the number of Sertoli cells determines the number of spermatozoa produced per day, it is important that the correct number of Sertoli cells is generated. The factors that determine the number of Sertoli cells must be partly genetic, although the relevant genes have yet to be identified, apart from the fragile $X$ gene, FMR-1 (Slegtenhorst-Eegdeman et al., 1998; Sharpe, 1999).

Hormones are important, in particular FSH and thyroid hormones, but also growth hormone and various paracrine growth factors (Sharpe, 1994, 1999), and even LH or testosterone may play a role in rhesus monkeys (Ramaswamy et al., 2000). FSH increases the rate of proliferation of Sertoli cells. In contrast, thyroid hormones alter the period in which proliferation can occur by regulating maturation of Sertoli cells. How thyroid hormones produce this effect is unclear, but it may involve effects on the size of Sertoli cells (and therefore their density in the epithelium). This interpretation is based primarily on experimental data from rats, and not all aspects may be applicable to other species. The experimental manipulations (in neonatal life) that have been undertaken in rats are shown (Table 1). These illustrate that the neonatal concentration of FSH is important, as its suppression reduces the final number of Sertoli cells by about $40 \%$, whereas experimental increase of $\mathrm{FSH}$ by injection or by neonatal hemicastration increases the number of Sertoli cells by $18-49 \%$. Induction of neonatal hypothyroidism has considerably larger effects, increasing the final number of Sertoli cells by $82-157 \%$, whereas induction of neonatal hyperthyroidism reduces the final number of Sertoli cells by about $50 \%$. The last two treatments may induce their effects by delaying (Hess et al., 1993; De Franca et al., 1995) or advancing (van Haaster et al., 1993), respectively, the age at which cessation of proliferation of Sertoli cells (= maturation) occurs. Whether thyroid hormones play a similar role in all species is uncertain, but untreated, juvenile hypothyroidism in humans can be associated with precocious and permanent testicular enlargement (Jannini et al., 1995; Sharpe, 1999).

Non-hormonal factors (for example growth factors) are also presumed to play a physiological role in proliferation or function of Sertoli cells, and effects of numerous growth factors have been described in vitro, and some in vivo (see for example Jégou 1992; Jégou and Sharpe, 1993); space precludes discussion of such effects in this review. Such studies also indicate that cell-contact inhibition (confluency) may play a role in cessation of proliferation of Sertoli cells, as is the case generally for epithelial cells (Schlatt et al., 1996).

\section{Variation in number of Sertoli cells}

Differences in testis size among species and within strains are explicable by differences in the number of Sertoli cells in animal studies (Sharpe, 1994, 1999; McCoard et al., 2001). Testis size and sperm count in the ejaculate always show a clear linear relationship in humans (see, for example, Bujan et al., 1989; Lenz et al., 


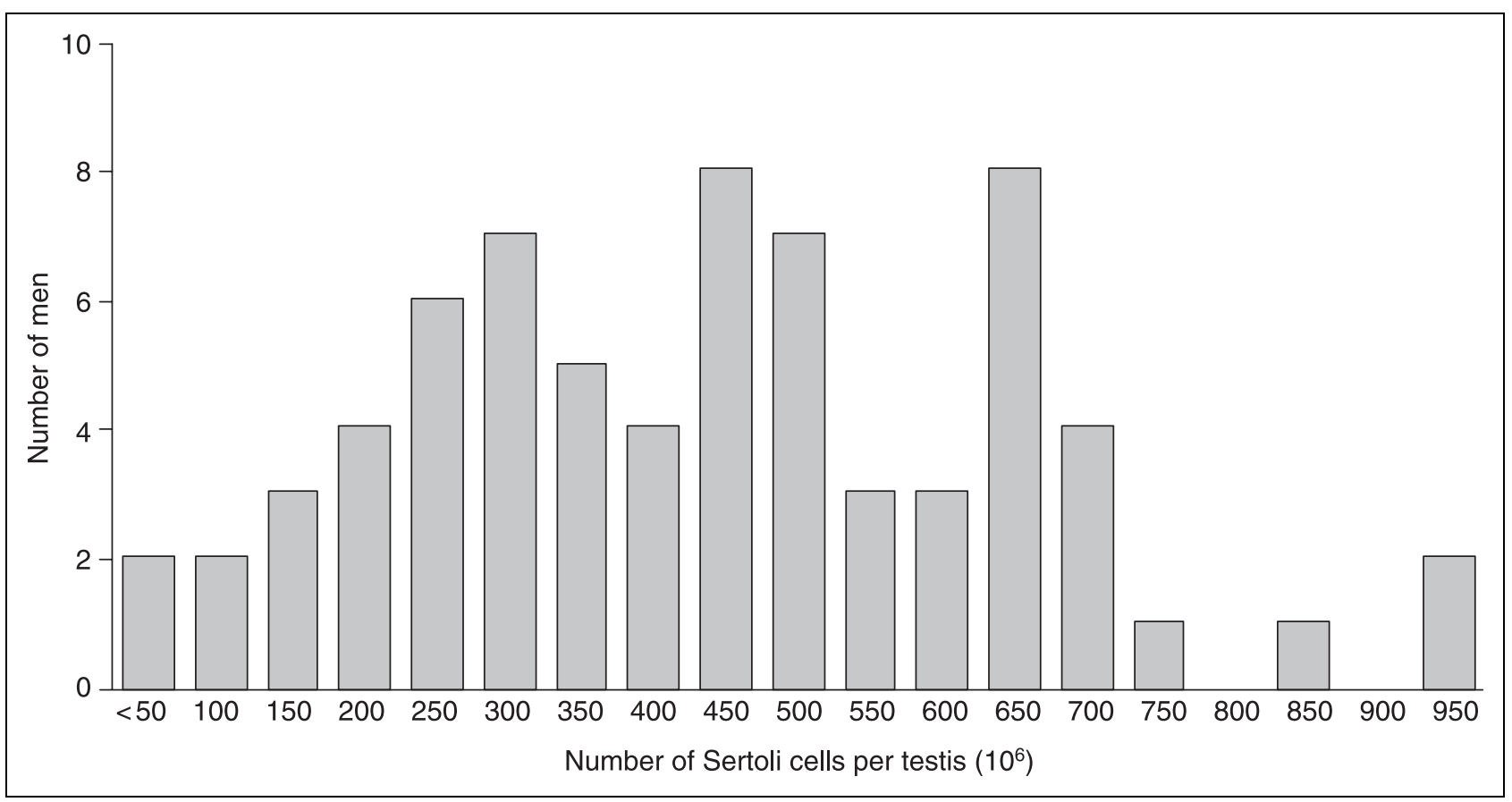

Fig. 2. Variation in number of Sertoli cells in the testes of adult men. The data have been extracted from a study by Johnson et al. (1984) of men who died suddenly from a variety of causes.

1993). As also shown in these studies, testicular size and sperm count show wide variation among men, and one interpretation is that variation in the number of Sertoli cells accounts for this (Sharpe, 1999; Sharpe and Franks, 2002). This interpretation is supported by the only study (Johnson et al., 1984) that has directly measured the number of Sertoli cells in the adult human testis and equated it to daily sperm production (based on germcell counts in the testis). This study showed a linear relationship between the number of Sertoli cells and daily sperm production, but also considerable variation in the number of Sertoli cells among men (Fig. 2). Other than evidence for a modest loss of Sertoli cells with ageing (Johnson et al., 1984), this variation was unexplained, but is presumed to result from events in fetal, neonatal or peripubertal life (Sharpe, 1999). Other evidence of high variation in the number of Sertoli cells is the equally high variation in blood concentrations of inhibin $B$ in otherwise normal men (see, for example, Jensen et al., 1997). Although secondary absence of germ cells can influence inhibin B concentrations (see below), high variation in blood concentrations of inhibin $B$ has also been reported neonatally in humans (Andersson et al., 1998) when Sertoli cells are proliferating.

Storgaard et al. (in press) highlight some of these relationships. This study has shown that smoking of $>10$ cigarettes per day by the mother during pregnancy results in a $30-48 \%$ reduction in sperm counts and testis size in adulthood in the exposed male with a corresponding $24 \%$ decrease in blood concentrations of inhibin B; other data confirm this work (Sharpe and Franks, 2002). On the basis of the change in inhibin B concentrations, and no evidence for any change in the morphology or motility of the spermatozoa according to exposure, Storgaard et al. (in press) concluded tentatively that the effect of maternal smoking probably reflected a reduction in the number of Sertoli cells. However, if the number of Sertoli cells was reduced in fetal life, it is unclear why compensatory adjustment did not take place neonatally or peripubertally, as these are important times for proliferation of Sertoli cells in humans (Fig. 1; Cortes et al., 1987). The mechanism via which maternal smoking affects proliferation of Sertoli cells in the fetus remains to be identified.

Recent studies have shown that in utero exposure of rats to certain phthalate esters can induce a spectrum of disorders similar to TDS (reviewed in Sharpe, 2001). These include reduced testis mass in adulthood (Mylchreest et al., 1998), and neonatal treatment with similar phthalates has been shown to reduce proliferation of Sertoli cells (Dostal et al., 1988; Li et al., 2000). The present authors' studies indicate that exposure in utero to phthalates may permanently arrest some Sertoli cells in an immature, fetal state, incapable of supporting spermatogenesis (Fisher et al., 2003). Though the effects of phthalates in rats have involved doses considerably higher than the documented exposure concentrations for humans (Sharpe, 2001), concerns remain that some individuals (mainly women of reproductive age) may have unusually high exposure to phthalates 
(Blount et al., 2000). The mechanisms via which phthalates affect development of Sertoli cells remain to be identified.

\section{Functional maturation of Sertoli cells}

At around the onset of puberty, Sertoli cells undergo a radical change in their morphology and function, heralding the switch from an immature, proliferative state to a mature, non-proliferative state. The nucleus enlarges and becomes tripartite and the nucleolus becomes more prominent (Fig. 3). Adjacent Sertoli cells form tight junctions with each other to create a unique adluminal compartment in which meiotic and post-meiotic steps of spermatogenesis can proceed, as well as allowing formation of a fluid-filled lumen. As a result, the germ cells developing in the adluminal compartment become effectively sealed off from direct access to many nutrients and thus become dependent on the secretion of such factors by the Sertoli cells. Accordingly, the Sertoli cell switches on these functions and they become a distinguishing feature of the 'mature' Sertoli cell (see Jégou 1992; McLaren et al., 1993; Sharpe, 1994). The expectation would be that many different functions would be expressed by mature adult Sertoli cells when compared with fetal, proliferating Sertoli cells, but there is a surprising lack of definitive comparative studies.

Whether maturation of Sertoli cells involves a rapid switch from an immature to a mature state or involves a step-wise cascade of changes that may occur over a period of time, is not entirely clear. Though some immature functions of Sertoli cells (for example, aromatase expression) show a clear switch at puberty, others (for example, $\mathrm{AMH}$ ) do not show such a sharp demarcation (see below). Irrespective of this debate, analysis of the expression of maturational markers of Sertoli cells can be potentially informative, especially in patients in whom disorders of sexual differentiation or testicular development are suspected. Maturational markers that have been studied are discussed below.

\section{Factors affecting maturation of Sertoli cells}

Before considering the protein markers of maturation of Sertoli cells, a key question to address is what induces maturation of Sertoli cells. As already mentioned, thyroid hormone $\left(T_{3}\right)$ plays a role in maturation of Sertoli cells in laboratory animals, and though it may play a role in other species, other factors may be involved. For example, in primates with a considerable delay to puberty, it seems likely that FSH, and particularly androgens, may play a role in final maturation of Sertoli cells as patients with complete androgen insensitivity syndrome (AIS) usually exhibit Sertoli cells that show various features of immaturity, such as persistence of $\mathrm{AMH}$ expression (Rey et al., 1994, 1999; Rajpert-de Meyts et al., 1999).
An obvious candidate for induction of maturation of Sertoli cells is the influence of newly differentiating germ cells. However, it is evident from both animal models and human patients that absence of germ cells does not result de facto in failure of maturation of Sertoli cells, though there may be a delay, such as in the formation of inter-Sertoli cell tight junctions (Means et al., 1976). Changes in secretory function of Sertoli cells secondary to the absence of particular types of germ cell can also occur (Jégou and Sharpe, 1993; Sharpe et al., 1993; Boujrad et al., 1995; Guitton et al., 1999; Fig. 3), and others have claimed that absence of germ cells can result in de-differentiation of Sertoli cells, such that functions of immature Sertoli cells are 'switched back on' (see below). However, it is important to recognize that absence of germ cells may also be a reflection of underlying abnormalities in the Sertoli cells, such as failure of their maturation (Fig. 3). The fact that the latter phenotype can occur in focal areas intermixed with other 'types' of seminiferous tubule (see below and Steger et al., 1996; Maymon et al., 2000) can create obvious problems with interpretation.

Although the evidence from laboratory animals indicates an important role for $\mathrm{T}_{3}$ in maturation of Sertoli cells, the most likely scenario is that $T_{3}$ interacts with androgens, and perhaps $\mathrm{FSH}$, to bring about final maturation of Sertoli cells, and that germ cells then exert modulating effects on these mature Sertoli cells. This implies a step-wise process of maturation. For example, in vitro studies in rats have shown that FSH and $T_{3}$ both induce androgen receptor (AR) expression in immature Sertoli cells (Arambepola et al., 1998a) and suppress AMH expression (Arambepola et al., 1998b), and the effects of FSH and $\mathrm{T}_{3}$ are additive. It is therefore envisaged that, in rats, rising FSH concentrations, which trigger proliferation of Sertoli cells, induce progressively increasing expression of $A R$, an effect that is upregulated by increasing effects of $T_{3}$ which will ultimately lead to functional maturation of the Sertoli cells and consequent loss of AMH expression. Changing sensitivity of Sertoli cells to $T_{3}$ during their proliferative phase, due to altered expression of $\mathrm{T}_{3}$ receptors (Buzzard et al., 2000), may be another contributing factor. However, this scenario may differ among species. Thus, in marmosets and humans there is no, or only weak, AR expression in Sertoli cells in the neonatal period despite high FSH concentrations (see, for example, Andersson et al., 1998) that are driving proliferation of Sertoli cells (Cortes et al., 1987; McKinnell et al., 2001). Thereafter, AR expression switches on in marmosets during infancy when $\mathrm{FSH}$ or testosterone concentrations are baseline and the Sertoli cells are clearly immature (McKinnell et al., 2001; Kelnar et al., 2002; see Figs 1 and 4). It is speculated that absence of sufficient $\mathrm{T}_{3}$, or more likely the absence of $T_{3}$ receptors in the Sertoli cell, prevent induction of AR during the neonatal period in marmosets and possibly in humans (Jannini et al., 2000). 


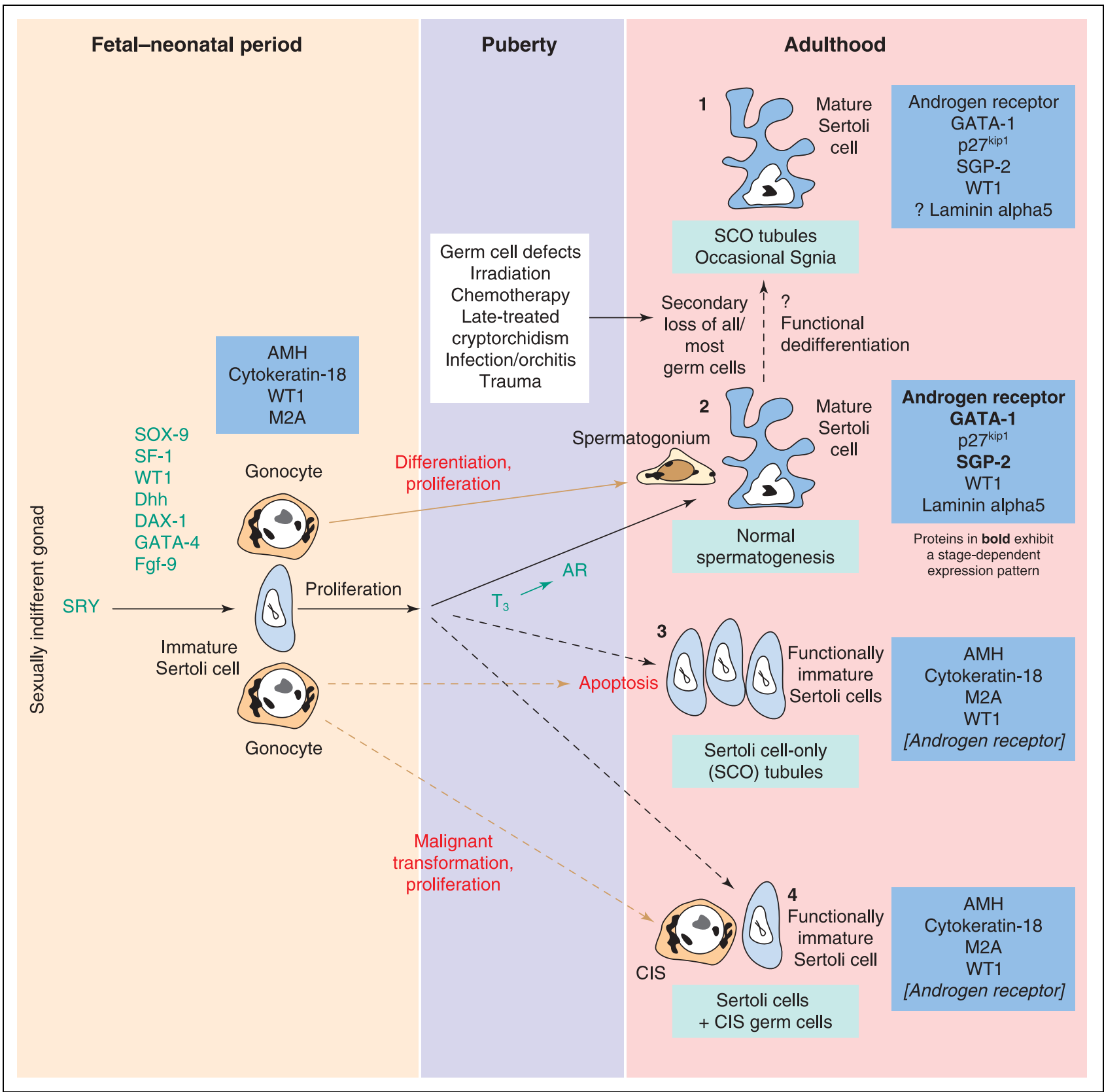

Fig. 3. Schematic diagram illustrating normal (and abnormal) maturational development of Sertoli cells from fetal life through puberty to adulthood, and the associated changes in expression of protein markers (blue boxes) of maturity or immaturity. The ability of Sertoli cells to support germ cells is also indicated. Note that only one of the scenarios in adulthood is normal (2), the other three $(1,3,4)$ represent conditions in which only isolated spermatogonia are present or tubules are Sertoli-cell only (SCO; 1$)$, or in which transformed fetal germ cells (carcinoma-in situ, CIS) are present (4). Testes exhibiting germ-cell arrest are not illustrated but would fall into categories 1 and 2. The main purpose of the diagram is to distinguish adult phenotypes in which Sertoli cells have failed to mature $(3,4)$ from those in which the Sertoli cells have matured $(1,2)$; the possibility of functional 'de-differentiation' of Sertoli cells, following germ-cell loss is covered by category 1 . Factors in green are those that play a role in initial differentiation or final maturation of Sertoli cells. Where factors in boxes are shown in parentheses, this indicates a degree of ambiguity or uncertainty, which is discussed in the text. SGP-2: sulphated glycoprotein 2; WT1: Wilms' tumour gene; AMH: anti-Mullerian hormone; $\mathrm{T}_{3}$ : thyroid hormone; AR: androgen receptor.

AR expression in Sertoli cells in humans is probably a late event in puberty (A. Waring, H. Wallace, C. Kelnar and R. Sharpe, unpublished). The rising concentrations of FSH and testosterone at puberty, coincident with AR expression in Sertoli cells, might enable their final maturation. 


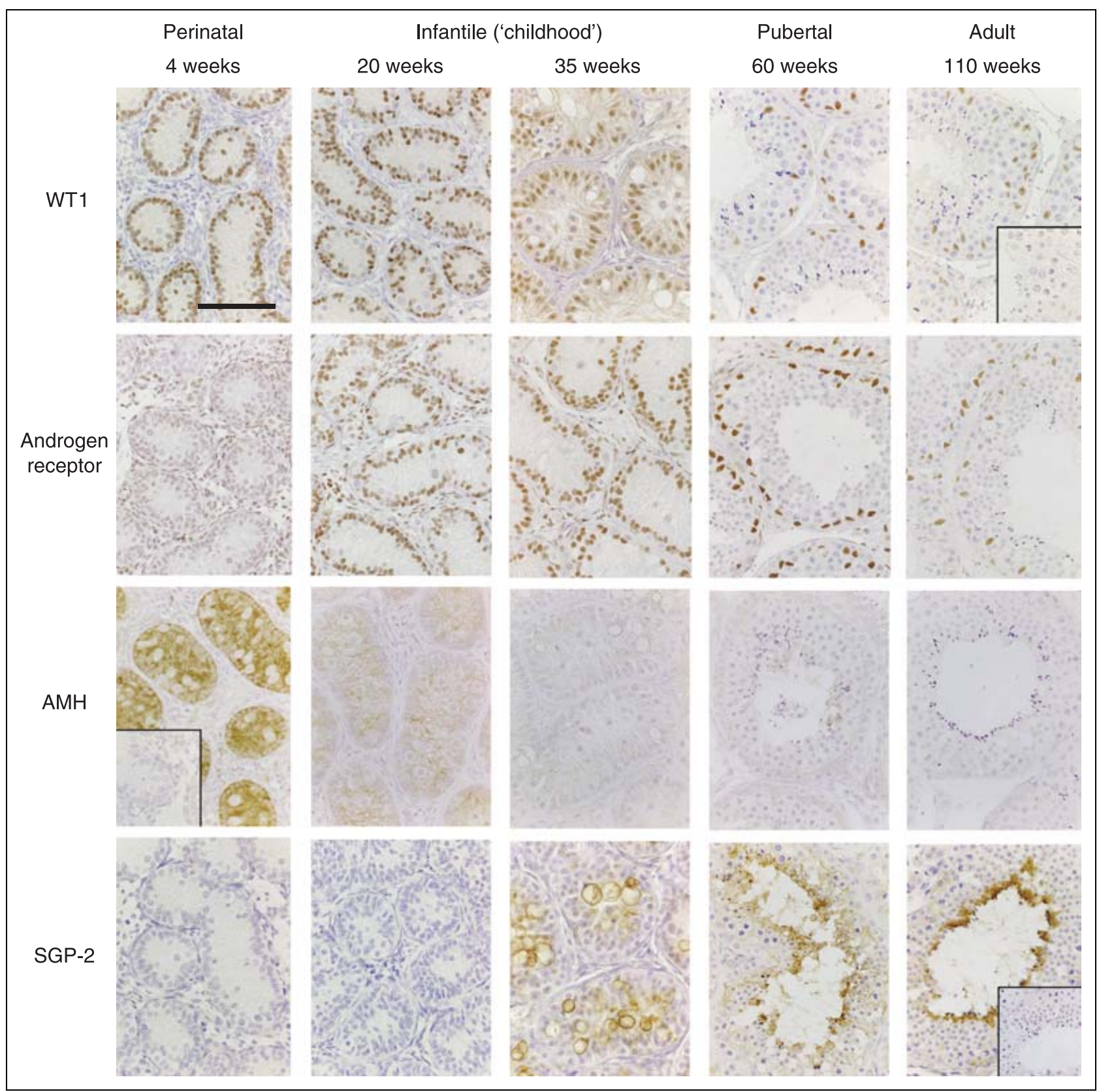

Fig. 4. Changes in the immunoexpression of four protein markers in Sertoli cells from birth to adulthood in marmosets, to illustrate the maturation-dependent patterns of expression. Nuclear immunoexpression of the Wilms' tumour gene (WT1) is evident in Sertoli cells at all ages and shows no obvious maturation-dependent changes. In contrast, nuclear immunoexpression of the androgen receptor is absent in the neonatal period but is apparent from about 20 weeks of age onwards with increased intensity of immunoexpression from 20 to 60 weeks of age. Cytoplasmic immunoexpression of anti-Mullerian hormone (AMH) in Sertoli cells is intense in neonatal life but expression diminishes gradually thereafter and is virtually absent from puberty onwards. In contrast, cytoplasmic immunoexpression of sulphated glycoprotein 2 (SGP-2) is absent until 35 weeks of age and later (note increased intensity of expression at later ages). Insets show negative controls in which the primary antibody was omitted or pre-absorbed by an excess of the immunizing peptide. Scale bar represents $100 \mu \mathrm{m}$.

From the information available, it seems most probable that maturation of Sertoli cells is a multi-step process or cascade, and that the precise timing of the different steps may vary according to species. Intrinsic to this explanation is the likelihood that disorders of maturation of Sertoli cells may occur at different steps and that failure to undergo an early step may prevent or interfere with future steps. This might explain observations such as 
the mixed patterns of Sertoli cell AR expression seen in SCO tubules in humans (especially in cryptorchid testes), in which Sertoli cells exhibiting immature nuclear morphology and not expressing AR may be intermixed with Sertoli cells with partly differentiated nuclei that express the AR weakly (Regadera et al., 2001).

\section{Protein markers of number, function or maturational status of Sertoli cells}

Although sperm count may provide a gross indication of function of Sertoli cells, it does not enable easy interpretation of whether there is an underlying deficit in the number, function or maturation of Sertoli cells. Measurement of blood concentrations of inhibin B has shown promise in this regard, as in humans, monkeys and rats it appears to be a specific product of Sertoli cells (reviewed in Anderson and Sharpe, 2000). Various studies have shown that in humans and rats, inhibin $B$ concentrations show their biggest and most rapid increase during the neonatal period (Andersson et al., 1998; Sharpe et al., 1999), when the number of Sertoli cells is increasing (Fig. 1), whereas in rhesus monkeys there is only a modest increase in inhibin B concentrations neonatally but a very pronounced increase peripubertally (Winters and Plant, 1999), when proliferation of Sertoli cells mainly occurs in this species (Fig. 1). In both rats (Sharpe et al., 1999) and rhesus monkeys (Ramaswamy et al., 1999), experimental manipulation of the number of Sertoli cells is matched by a corresponding change in concentrations of inhibin B. Blood concentrations of inhibin B are extremely variable in adult men (see, for example, Jensen et al., 1997), and though this may reflect variation in the number of Sertoli cells, as described above, it is apparent that other factors are also influential. In particular, the status of spermatogenesis is important, and loss of particular types of germ cell can lead to a marked reduction in blood concentrations of inhibin B (Foppiani et al., 1999; Anderson and Sharpe, 2000). Therefore, though a positive relationship between sperm counts and blood inhibin B concentrations in adult men is evident at the population level (see, for example, Jensen et al., 1997; Pierik et al., 1998), consistent with this reflecting differences in the number of Sertoli cells, it is not possible to interpolate confidently the number of Sertoli cells from the inhibin B concentrations in individual men.

Men with oligozoospermia may undergo testicular biopsy, and this affords the opportunity to investigate directly the functional or maturational status of the Sertoli cells. Expression of certain proteins is clearly associated with immaturity or maturity of the Sertoli cell, and study of the immunoexpression of such markers can potentially aid interpretation of various seminiferous tubule phenotypes that may present. Such studies might indicate whether there has been a fundamental failure of maturation of Sertoli cells (Fig. 3). If maturation of
Sertoli cells occurs as a cascade, better understanding of when various protein markers are expressed in relation to acquisition of maturation of Sertoli cells may provide pointers as to when the maturation process failed. At present there is a lack of sufficient detailed understanding to use the available information in this way. Immunoexpression in Sertoli cells of four of the protein markers described below is shown (Fig. 4), as exhibited by marmosets, which show similar developmental phases to humans, but measured in months rather than years (Kelnar et al., 2002). This illustrates how different proteins may signal the maturational status of the Sertoli cell. Data for immunoexpression of WT1 and $\mathrm{p} 27^{\mathrm{Kip} 1}$ in rats are shown (Fig. 5) for the same purpose.

\section{Wilms' tumour gene (WT1)}

The transcription factor WT1 is switched on in Sertoli cells early in fetal life (Mackay, 2000). Thereafter, it continues to be expressed in Sertoli cells, localized primarily to the nucleus, throughout all phases of life (Figs 4 and 5). It provides a stable marker of Sertoli cells, against which other protein markers can be compared.

\section{Anti-Mullerian hormone $(\mathrm{AMH})$}

$\mathrm{AMH}$ is one of the first genes to be switched on in Sertoli cells after their differentiation in fetal life (Mackay, 2000; Josso et al., 2001), and expression continues while Sertoli cells remain immature (Fig. 4). At puberty, $\mathrm{AMH}$ expression in Sertoli cells and its secretion into the bloodstream is severely downregulated, coincident with the appearance of meiotic germ cells and androgen sensitivity of the Sertoli cell, and also with final maturation of the Sertoli cells (Rey et al., 1994, 1999; Rajpert-de Meyts et al., 1999). Absence of germ cells due to prepubertal testicular irradiation does not prevent downregulation of AMH at puberty (Rajpert-de Meyts et al., 1999). Persistence of high AMH expression in Sertoli cells or high concentrations in blood in adulthood may indicate failure of maturation of Sertoli cells (Fig. 3), though it can also reflect deficiencies in androgen action (see below).

\section{Aromatase}

This P450 enzyme is expressed in fetal or neonatal Sertoli cells but expression is downregulated during maturation (Palmero et al., 1995; Panno et al., 1995), such that in the adult rat testis, aromatase is expressed mainly in Leydig cells and in certain germ cells (Carreau et al., 1999; Turner et al., 2002). Together with other markers of immature Sertoli cells in rats, aromatase expression is downregulated by exposure to $T_{3}$ (see, for example, Ulisse et al., 1994; Palmero et al., 1995; Ando et al., 2001). It is uncertain whether downregulation of aromatase, as a feature of maturation of Sertoli cells, 


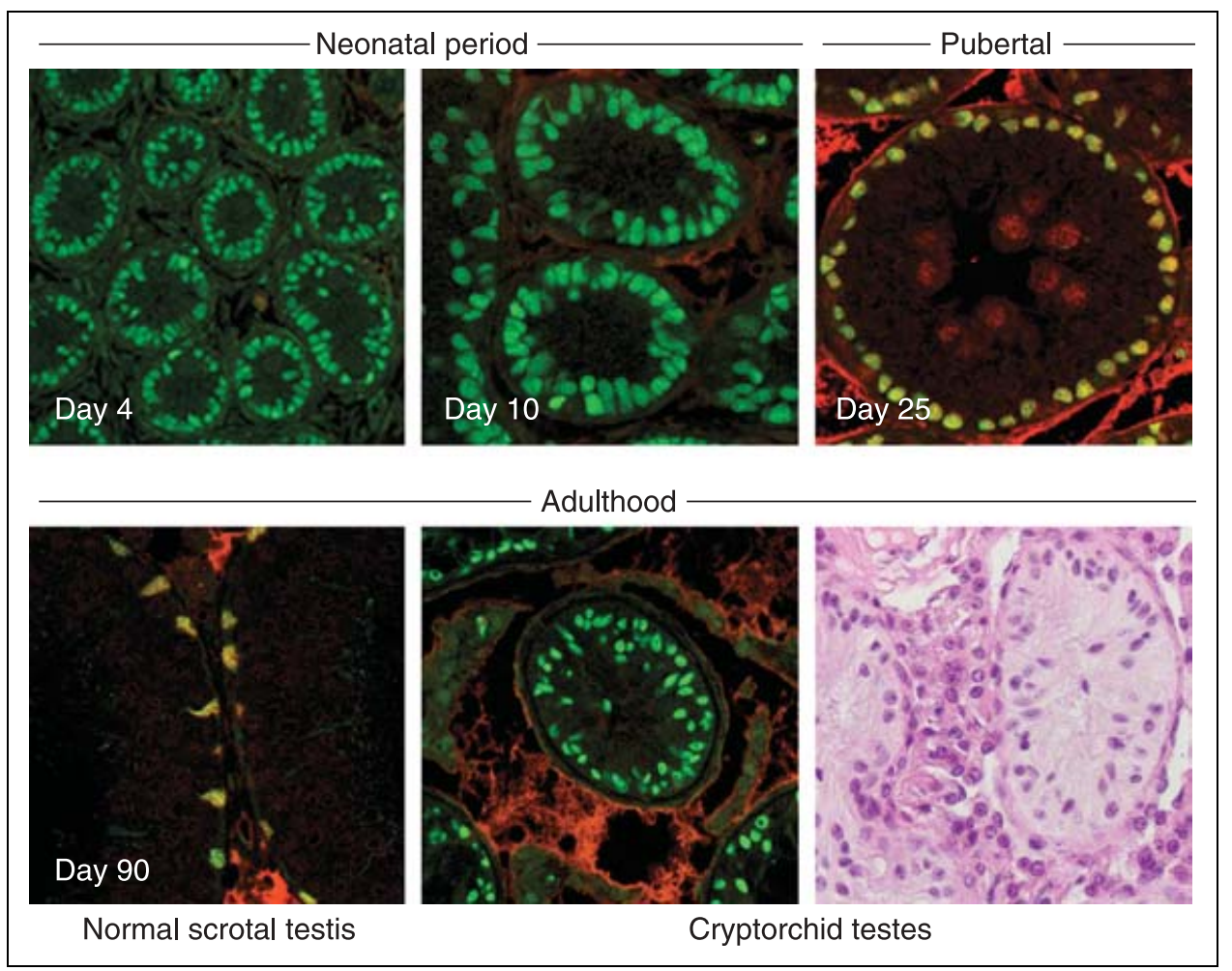

Fig. 5. Maturation-dependent change in Sertoli-cell nuclear protein expression in rats, on the basis of co-immunoexpression of $\mathrm{p} 27^{\mathrm{kip} 1}$ by Sertoli cells and the constant Sertoli-cell marker, WT1 (Wilms' tumour gene). Figures shown are confocal images with green nuclear fluorescence indicating nuclear immunoexpression of WT1 alone and yellow nuclear fluorescence indicating nuclear immunoexpression of both WT1 and p2 $7^{\text {kip } 1}$. Note that no cells exhibit red-only nuclear fluorescence (that is, immunoexpression of $\mathrm{p} 27^{\mathrm{kip} 1}$ but not WT1), though there is some background red fluorescence. Note that co-expression of $\mathrm{p} 27^{\mathrm{kip} 1}$ with WT1 is only evident beyond 25 days of age. Also depicted is the lack of p2 $7^{\mathrm{kip} 1}$ immunoexpression (indicative of failure of normal maturation) in nuclei of Sertoli cells in a Sertoli cell-only (SCO) tubule from the cryptorchid testis of an adult rat that had been exposed in utero to dibutyl phthalate (see Fisher et al., 2003). The morphological appearance of such SCO tubules, in which maturation of Sertoli cells has not occurred, is shown in the lower right-hand panel.

is specific to the rat or occurs in most species; this uncertainty stems from the low protein expression of aromatase in the testis (Turner et al., 2002). The role of oestrogens produced by immature Sertoli cells is not understood, but it is remarkable that knockout of the genes for either aromatase or for oestrogen receptors $\alpha$ and $\beta$ can result in the latent appearance of 'Sertolilike' cells in the ovaries of females (Couse et al., 1999; Brit et al., 2002). This finding implies a role for oestrogens in maintenance of granulosa-cell or Sertolicell differentiation, and maturational loss of aromatase expression in Sertoli cells may be important for this reason.

\section{Neural cell adhesion molecule (NCAM)}

NCAM is expressed by fetal or immature Sertoli cells and is probably important for gonocyte adhesion during their intratubular migration to the basement membrane (Laslett et al., 2000; Orth et al., 2000). Expression of NCAM is downregulated in the rat during maturation of Sertoli cells (Orth and Jester, 1995; Orth et al., 2000) and can be downregulated experimentally by administration of $\mathrm{T}_{3}$ (Laslett et al., 2000), consistent with this interpretation. It is unknown if failure of maturation of Sertoli cells results in persistence of NCAM expression, but if this does occur it might determine whether fetal germ cells and carcinoma in situ (CIS) cells could survive without differentiating into spermatogonia (Fig. 3).

\section{Cytokeratin 18}

Cytokeratin 18, a marker of intermediate filaments, is expressed in epithelial cells, including Sertoli cells. In humans, cytokeratin 18 is a robust marker of immature Sertoli cells and in adult testes it has been used to 
identify seminiferous tubules in which the Sertoli cells have not matured (Stosiek et al., 1990; Steger et al., 1996, 1999; Maymon et al., 2000), though this has also been indicated as reflecting de-differentiation of mature Sertoli cells (Kliesch et al., 1998; Steger et al., 1999).

\section{Laminin alpha5}

Deposition of a basement membrane is an integral feature of seminiferous cord formation and the component parts may change during maturation and reflect the status of Sertoli cells. One such factor is laminin alpha5, the expression of which is inversely related to that of $\mathrm{AMH}$ in the rat (Pelliniemi and Frojdman, 2001). It is unknown whether failure of maturation of Sertoli cells results in absence of laminin alpha5 expression.

\section{GATA-1}

GATA- 1 is a transcription factor that is first expressed in Sertoli cells in mice as they are maturing, during the first wave of spermatogenesis (Yomogida et al., 1994). Initially, GATA-1 is immunoexpressed by all Sertoli cells but, as spermatogenesis expands, its expression becomes stage-dependent, and absence of germ cells in various mutant mice strains results in uniform Sertoli-cell expression of GATA-1 (Yomogida et al., 1994). GATA-1 is therefore a protein marker of mature Sertoli cells, but with secondary modulation by later types of germ cell (see also Jégou and Sharpe, 1993). Expression of GATA-1 and $\mathrm{AMH}$ are inversely related during testis development and GATA-1 may switch off AMH expression during maturation of Sertoli cells (Beau et al., 2000), and may upregulate expression of other Sertoli cell genes (Feng et al., 2000). It is not known whether failure of maturation of Sertoli cells results in absence of GATA-1 expression.

\section{p2 $7^{\text {Kip1 }}$}

$\mathrm{p} 27^{\mathrm{Kip} 1}$, a cyclin-dependent kinase inhibitor, plays a role in the cell cycle; its expression is associated normally with inhibition of proliferation. Accordingly, immunoexpression of $\mathrm{p} 27^{\mathrm{Kip} 1}$ coincides with maturation of Sertoli cells in mice (Beumer et al., 1999; Cipriano et al., 2001), rats (Fig. 5) and humans (Beumer et al., 1999). Failure of maturation of Sertoli cells in rats results in absence of $\mathrm{p} 27^{\mathrm{Kip} 1}$ expression, in contrast to the continued expression of WT1 (Fig. 5).

\section{M2A antigen}

$\mathrm{M} 2 \mathrm{~A}$ is an unidentified antigen that is recognized by a monoclonal antibody. M2A is expressed only by immature and not mature Sertoli cells in humans (Baumal et al., 1989), and its expression may persist in patients in whom disorders of spermatogenesis are present (Steger et al.,1999; Blagosklonova et al., 2002).

\section{Androgen receptor (AR)}

Nuclear immunoexpression of $A R$ is a feature of mature Sertoli cells, though expression varies according to the stage of the spermatogenic cycle in rats (Bremner et al., 1994) and humans (Suarez-Quian et al., 1999). However, AR immunoexpression does not coincide exactly with maturation of Sertoli cells in any of the species studied, but first appears before final maturation of Sertoli cells, in which it may play a role. In fetal and early neonatal life, Sertoli cells do not express AR in rats, humans or marmoset monkeys (Fig. 4; Williams et al., 2001). In rats, Sertoli cell nuclear AR immunoexpression becomes evident at age $4-8$ days (that is, before cessation of proliferation of Sertoli cells; Bremner et al., 1994), whereas in the marmoset monkey it occurs at the end of the neonatal period (Fig. 4) when Sertoli cells are still immature (Fig. 4; Kelnar et al., 2002), and in humans it probably does not occur until close to the onset of puberty (A. Waring, H. Wallace, C. Kelnar and R. Sharpe, unpublished). Failure of maturation of Sertoli cells in humans, based on nuclear and general morphology, can be associated with absent or weak AR expression (Regadera et al., 2001); weak expression might be indicative of maturational failure at a later step than in Sertoli cells that show no expression of AR.

\section{Persistence of immature Sertoli cells in testes with disorders of spermatogenesis}

Failure of a Sertoli cell to mature functionally will presumably render it incapable of supporting the survival and development of the various germ cells that appear after puberty. However, immature (fetal) Sertoli cells are clearly capable of supporting fetal germ cells (primordial germ cells, gonocytes) and immature, neonatal or infantile Sertoli cells are capable of supporting spermatogonia. Persistence of immature Sertoli cells in the adult testis would therefore be inconsistent with full spermatogenesis, though in theory such cells might be capable of supporting the survival of normal or transformed (CIS) fetal germ cells or early spermatogonia (Fig. 3). It is also established that the presence of particular meiotic and post-meiotic germ cells has profound effects on the function of mature Sertoli cells (Jégou and Sharpe, 1993; Sharpe et al., 1993; Boujrad et al., 1995), and their absence (for example due to exposure to irradiation) may lead to secondary changes in Sertoli-cell function such that they bear some functional resemblance to immature Sertoli cells (Fig. 3). When an SCO tubule is observed in the adult testis, how is the mature Sertoli cell that has lost its germ cells distinguished from the 'failure of maturation' type of Sertoli cell? Until fairly recently, the distinction has relied firmly on morphological criteria, such as the persistence of small, spindle-shaped Sertoli-cell nuclei arranged closely in a pallisade in immature Sertoli cells and with 
no evidence of formation of a lumen (see Paniagua et al., 1990; Pinart et al., 2000; Nistal et al., 2002; Fig. 5). These seminiferous tubules are commonly described in cryptorchid testes, but are also reported in scrotal testes of some patients with Klinefelters syndrome (see, for example, Nistal et al., 1982), impaired spermatogenesis (see, for example, Regadera et al., 2001) or testicular germ-cell cancer (see, for example, Stosiek et al., 1990; Kliesch et al., 1998).

\section{Immunohistochemical evidence for immaturity of Sertoli cells in various pathologies}

In human testes with various disorders, some, but not all, SCO tubules express one or more markers of immature Sertoli cells such as AMH, cytokeratin 18 and M2A, and may not express antigens such as AR that are normal features of mature Sertoli cells (Fig. 3). These findings have been interpreted as evidence either for the persistence of immature Sertoli cells (see, for example, Maymon et al., 2000, 2002) or, in some instances, as de-differentiation of mature Sertoli cells such that certain immature functions have been re-expressed (see, for example, Kliesch et al., 1998; Steger et al., 1999; Young et al., 1999; Brehm et al., 2002). It is difficult to distinguish failure of maturation, which may occur at various steps, from de-differentiation, unless there are obvious differences such as in nuclear morphology. If de-differentiation of Sertoli cells secondary to the loss of germ cells is a real phenomenon, it is clearly not an inevitable consequence of germ-cell loss, as is illustrated by the loss of germ cells from the prepubertal testis of boys who have been treated for cancer. In these otherwise normal boys, pubertal loss of features of immature Sertoli cells, such as expression of AMH, still occurs though perhaps with some delay (Rajpert-de Meyts et al., 1999). Irradiation-induced loss of germ cells from the adult testis also fails to alter the differentiation status of Sertoli cells (Giwercman et al., 1991). In a similar way, loss of $\mathrm{AMH}$ and cytokeratin 18 immunoexpression in Sertoli cells also occurs normally in most (but not all) azoospermic men either with idiopathic absence of germ cells (Rajpert-de Meyts et al., 1999), or associated with Y-chromosome microdeletions (Maymon et al., 2000; Blagosklonova et al., 2002); in oligozoospermic men with germ-cell maturation arrest, similar absence of markers of immature Sertoli cells is evident in most men (Maymon et al., 2000, 2002; Blagosklonova et al., 2002).

Though the above indicates that $\mathrm{AMH}$ expression reflects maturational status of Sertoli cells, this is an over-simplification. Patients with congenital hypogonadotrophic hypogonadism $(\mathrm{HH})$, in whom puberty is consequently delayed, exhibit continued high blood concentrations of $\mathrm{AMH}$, consistent with failure of maturation of Sertoli cells (Young et al., 1999). However, patients with acquired $\mathrm{HH}$, in whom normal puberty had earlier occurred, also show a (smaller) increase in blood $\mathrm{AMH}$ concentrations, and treatment of these men with hCG or testosterone suppresses AMH concentrations to normal adult concentrations (Young et al., 1999). This result implies that $\mathrm{AMH}$ reflects status of androgen action on the Sertoli cell, though androgen responsiveness and maturation of Sertoli cells may be coincident, as already discussed. This interpretation is reinforced by studies in patients with complete AIS, in whom the Sertoli cells retain immature morphological and functional features such as expression of AMH (Rajpert-de Meyts et al., 1999; Regadera et al., 1999; Rey et al., 1999). Moreover, in some men with impaired spermatogenesis, especially those who exhibit focal SCO with morphologically immature Sertoli cells, focal expression of AMH and cytokeratin 18 (Steger et al., 1996; Rajpert-de Meyts et al., 1999; Maymon et al., 2000, 2002) and absence of AR expression (Regadera et al., 2001) are evident, consistent with failure of maturation of Sertoli cells in these regions. A similar association is frequently seen in men with testicular germ-cell cancer, in particular the association of Sertoli cells with an immature phenotype and the presence of pre-cancerous CIS cells (Fig. 3; Rogatsch et al., 1996; Kliesch et al., 1998; Brehm et al., 2002). However, in such cases it is difficult to distinguish whether continued $\mathrm{AMH}$ expression occurs because of the failure of maturation of Sertoli cells or because of failure of expression of androgen receptor, as the latter would result from the former.

In the authors' opinion, the occurrence of immature functional features of Sertoli cells in the testes of adult men with various abnormalities, in particular foci of abnormal seminiferous tubules, are most likely a reflection of failure of maturation rather than re-emergence of an immature phenotype due to de-differentiation of previously mature Sertoli cells. This would explain why such immature Sertoli cells occur most commonly in cryptorchid testes or in testes with germ-cell cancer or CIS, as these conditions originate in fetal life (Skakkebaek et al., 2001). In a similar way, persistence of immature Sertoli cells in patients with complete AIS, who are at high risk of CIS and testis cancer, and in whom the failure of maturation has a ready explanation (absence of the AR), is consistent with this view. This interpretation also fits with the hypothesized 'testicular dysgenesis syndrome' in humans, in which fundamental dysfunction of Sertoli cells or Leydig cells is believed to underlie the risk of cryptorchidism, testis cancer and some cases of impaired spermatogenesis (Skakkebaek et al., 2001; Sharpe and Skakkebaek, in press). The present findings in rats are entirely consistent with this hypothesis, as they show that treatments that result in focal persistence of immature Sertoli cells are associated with a high incidence of cryptorchidism, spermatogenic impairment, SCO tubules and infertility and abnormal development of fetal germ cells (Fisher et al., 2003). Nevertheless, in these situations it is common to find SCO tubules 
in which the Sertoli cells are immature alongside SCO or normal tubules in which the Sertoli cells are functionally mature (that is, not expressing immature Sertoli-cell markers; Fig. 3). In animals, similar foci of apparently immature Sertoli cells (mainly on the basis of morphology) in SCO tubules have been described, usually in cryptorchid testes (see, for example, Pinart et al., 2000). These findings support the view that the associated cryptorchidism may be a consequence, rather than the cause, of impaired maturation or development of Sertoli cells (Skakkebaek et al., 2001). Another potential implication is that the presence of foci of immature Sertoli cells might be indicative of more subtle, but more widespread, disturbance of maturation or function of Sertoli cells, such that some impairment of spermatogenesis occurs even in seminiferous tubules exhibiting complete spermatogenesis. However, account must be taken of changes in function of Sertoli cells that occur secondary to subnormal androgen action, as may occur with $\mathrm{AMH}$.

\section{Future perspectives}

Recognition that immature Sertoli cells may persist from fetal or prepubertal life and are always associated with absence of normal, or even any, spermatogenesis, is a conceptual step forward. It puts the emphasis on early development as the cause of the problem and thus raises the all-important questions of why, how and when the process of maturation of Sertoli cells has gone wrong. How can immature, dysfunctional Sertoli cells persist next to normal mature, fully functional Sertoli cells in the same testis? This seems to indicate that very early events in differentiation of Sertoli cells are at fault, which then render the Sertoli cell non-responsive to the normal cues that drive its step-wise maturation, absence of a functional AR being a case in point. If this dysfunction occurs during fetal life, it may also compromise normal proliferation of the affected cells in postnatal life (Fig. 1), and thus contribute to lowering the sperm count in such individuals. This poses numerous fascinating questions relating to the mechanics of Sertoli-cell and sexual differentiation, but it also has important health implications. The incidence of testicular cancer has doubled approximately every 30 years in Caucasian men in Western countries, such that lifetime risk is now 0.3$0.8 \%$, whereas cryptorchidism remains the commonest congenital malformation in children, affecting $2-4 \%$ of boys at birth (Sharpe and Skakkebaek, in press). Cryptorchidism is the most important risk factor for testicular cancer as well as being an important risk factor for low sperm counts (Sharpe and Skakkebaek, in press). If the incidence of testicular cancer is a beacon, signalling that the occurrence of TDS is increasing (Skakkebaek et al., 2001), then a better functional understanding of the development and maturation of early Sertoli cells may help to pinpoint how and when this might be affected by our modern lifestyle and environment (Sharpe and Franks, 2002). Studies in dysfunctional human testes that seek to establish the precise point(s) of arrest in differentiation or maturation of Sertoli cells should prove informative in this regard. However, studies in animal models which can shed light on the precise cascade of events in the development of Sertoli cells and can identify how arrest at various points may manifest at birth and in adulthood, will also be essential to link definitively events in utero with testicular function in adulthood. In turn, this understanding is likely to explain how transformed fetal germ cells (CIS) can survive into adulthood and give rise to testicular germ-cell cancer, as the persistence of immature Sertoli cells in association with such cells is a common feature, and may perhaps be essential before puberty.

\section{References}

Key references are identified by asterisks.

Anderson RA and Sharpe RM (2000) Regulation of inhibin secretion in the human male and its clinical applications. A Review International Journal of Andrology 23 136-144

Andersson A-M, Toppari J, Haavisto A-M, Petersen JH, Simell T, Simell O and Skakkebaek NE (1998) Longitudinal reproductive hormone profiles in infants: peak of inhibin B levels in infant boys exceeds levels in adult men Journal of Clinical Endocrinology and Metabolism 83 675-681

Ando S, Sirianni R, Forastieri P, Casaburi I, Lanzino M, Rago V, Giordano F, Giordano C, Carpino A and Pezzi V (2001) Aromatase expression in prepubertal Sertoli cells: effect of thyroid hormone Molecular and Cellular Endocrinology 178 11-21

Arambepola NK, Bunick D and Cooke PS (1998a) Thyroid hormone effects on androgen receptor messenger RNA expression in rat Sertoli and peritubular cells Journal of Endocrinology 156 43-50

Arambepola NK, Bunick D and Cooke PS (1998b) Thyroid hormone and follicle stimulating hormone regulate Mullerian-inhibiting substance messenger ribonucleic acid expression in cultured neonatal rat Sertoli cells Endocrinology 139 4489-4495

Atanassova N, McKinnell C, Walker M, Turner KJ, Fisher JS, Morley M, Millar MR, Groome NP and Sharpe RM (1999) Permanent effects of neonatal estrogen exposure in rats on reproductive hormone levels, Sertoli cell number, and the efficiency of spermatogenesis in adulthood Endocrinology 140 5364-5373

Baumal R, Bailey D, Giwercman A, Skakkebaek NE, Stratis M and Marks A (1989) A novel maturation marker for human Sertoli cells International Journal of Andrology 12 354-359

Beau C, Rauch M, Joulin V, Jegou B and Guerrier D (2000) GATA-1 is a potential repressor of anti-Mullerian hormone expression during the establishment of puberty in the mouse Molecular Reproduction and Development 56 124-138

* Beumer TL, Kiyokawa H, Roepers-Gajadien HL, van den Bos LA, Lock TM, Gademan IS, Rutgers DH, Koff A and de Rooij DG (1999) Regulatory role of p27kip1 in the mouse and human testis Endocrinology 1401834 1840

Blagosklonova O, Joanne C, Roux C, Bittard H, Fellmann F and Bresson JL (2002) Absence of anti-Mullerian hormone (AMH) and M2A immunoreactivities in Sertoli cell-only syndrome and maturation arrest with and without AZF microdeletions Human Reproduction 172062 2065

Blount BC, Silva MJ, Caudhill SP, Needham LL, Pirkle JL, Sampson EJ, Lucier GW, Jackson J and Brock JW (2000) Levels of seven urinary phthalate metabolites in a human reference population Environmental Health Perspectives 108 979-982

Boujrad N, Hocherau-de Reviers MT and Carreau S (1995) Evidence for germ cell control of Sertoli cell function in three models of 
germ cell depletion in the adult rat Biology of Reproduction $\mathbf{5 3}$ 1345-1352

Brehm R, Marks A, Rey R, Kliesch S, Bergmann M and Steger K (2002) Altered expression of connexins 26 and 43 in Sertoli cells in seminiferous tubules infiltrated with carcinoma-in-situ or seminoma Journal of Pathology 197 647-653

Bremner WJ, Millar MR, Sharpe RM and Saunders PTK (1994) Immunohistochemical localisation of androgen receptors in the rat testis: evidence for stage-dependent expression and regulation by androgens Endocrinology 135 1227-1234

Britt KL, Kerr JB, O'Donnell L, Jones MEE, Drummond AE, Davis SR, Simpson ER and Findlay JK (2002) Estrogen regulates the development of the somatic cell phenotype in the eutherian ovary FASEB Journal $\mathbf{1 6}$ 1389-1397

Bujan L, Mieusset R, Mansat A, Moatti JP, Mondinat C and Pontonnier F (1989) Testicular size in infertile men: relationship to semen characteristics and hormonal blood levels British Journal of Urology 64 632-637

Buzzard JJ, Morrison JR, O'Bryan MK, Song Q and Wreford NG (2000) Developmental expression of thyroid hormone receptors in the rat testis Biology of Reproduction 62 664-669

Carreau S, Genissel C, Bilinska B and Levallet J (1999) Sources of oestrogen in the testis and reproductive tract of the male International Journal of Andrology 22 211-223

Cipriano SC, Chen L, Burns KH, Koff A and Matzuk MM (2001) Inhibin and p27 interact to regulate gonadal tumorigenesis Molecular Endocrinology 15 985-996

Cortes D, Muller J and Skakkebaek NE (1987) Proliferation of Sertoli cells during development of the human testis assessed by stereological methods International Journal of Andrology 10 589-596

Couse JF, Hewitt SC, Bunch DO, Sar M, Walker VR, Davis BJ and Korach KS (1999) Postnatal sex reversal of the ovaries in mice lacking estrogen receptor alpha and beta Science $\mathbf{2 8 6} 2328-2331$

De Franca LR, Hess RA, Cooke PS and Russell LD (1995) Neonatal hypothyroidism causes delayed Sertoli cell maturation in rats treated with propylthiouracil: evidence that the Sertoli cell controls testis growth Anatomical Record 242 57-69

De Franca LR, Silva VAS, Jr, Chiarini-Garcia H, Garcia K and Debeljuk L (2000) Cell proliferation and hormonal changes during postnatal development of the testis in the pig Biology of Reproduction 63 1629-1636

Dostal LA, Chapin RE, Stefanski SA, Harris MW and Schwetz BA (1988) Testicular toxicity and reduced Sertoli cell numbers in neonatal rats by di (2-ethylhexyl) phthalate and recovery of fertility as adults Toxicology and Applied Pharmacology 95 104-121

Feng ZM, Wu AZ, Zhang Z and Chen CL (2000) GATA-1 and GATA4 transactivate inhibin/activin beta-B-subunit gene transcription in testicular cells Molecular Endocrinology 14 1820-1835

${ }^{*}$ Fisher JS, Macpherson S, Marchetti $\mathbf{N}$ and Sharpe RM Human 'testicular dysgenesis syndrome': a possible model based on in utero exposure of the rat to dibutyl phthalate Human Reproduction (in press)

Foppiani L, Schlatt S, Simoni M, Weinbauer GF, Hacker-Klom U and Nieschlag E (1999) Inhibin B is a more sensitive marker of spermatogenic damage than $\mathrm{FSH}$ in the irradiated non-human primate model Journal of Endocrinology 162 393-400

Giwercman A, von der Maase H, Berthelsen JG, Rorth M, Bertelsen A and Skakkebaek NE (1991) Localized irradiation of testes with carcinoma in situ: effects on Leydig cell function and eradication of malignant germ cells in 20 patients Journal of Clinical Endocrinology and Metabolism 73 596-603

Guitton N, Touzalin AM, Sharpe RM, Cheng CY, Pinon-Lataillade G, Meritte H, Chenal C and Jégou B (2000) Regulatory influence of germ cells on Sertoli cell function in the prepubertal rat after acute irradiation of the testis International Journal of Andrology 23 332-339

Hess RA, Cooke PS, Bunick D and Kirby JD (1993) Adult testicular enlargement induced by neonatal hypothyroidism is accompanied by increased Sertoli and germ cell numbers Endocrinology 132 26072613

${ }^{*}$ Hoei-Hansen CE, Holm M, Rajpert-de Meyts E and Skakkebaek NE
Histological evidence of testicular dysgenesis in contralateral biopsies from 218 patients with testicular germ cell cancer Journal of Pathology (in press)

Hutson JM, Hasthorpe S and Heyns CF (1997) Anatomical and functional aspects of testicular descent and cryptorchidism Endocrine Reviews $\mathbf{1 8}$ 259-280

Jannini EA, Ulisse S and D'Armiento M (1995) Thyroid hormone and male gonadal function Endocrine Reviews 16 443-459

Jannini EA, Crescenzi A, Rucci N, Screponi E, Carosa E, de Matteis A, Macchia E, d'Amati G and D'Armiento M (2000) Ontogenetic pattern of thyroid hormone receptor expression in the human testis Journal of Clinical Endocrinology and Metabolism 85 3453-3457

Jégou B (1992) The Sertoli cell Bailliere's Clinical Endocrinology and Metabolism 6 273-311

Jégou B and Sharpe RM (1993) Paracrine mechanisms in testicular control. In Molecular Biology of the Male Reproductive System pp 271-310 Ed. DM de Kretser. Academic Press, New York

Jensen TK, Andersson AM, Hjollund NH et al. (1997) Inhibin B as a serum marker of spermatogenesis: correlation to differences in sperm concentration and follicle-stimulating hormone levels. A study of 349 Danish men Journal of Clinical Endocrinology and Metabolism 824059 4063

Johnson L, Zane RS, Petty CS and Neaves WB (1984) Quantification of the human Sertoli cell population: its distribution, relation to germ cell numbers and age-related decline Biology of Reproduction 31 785-795

Josso N, di Clemente N and Gouedard L (2001) Anti-Mullerian hormone and its receptors Molecular and Cellular Endocrinology 179 25-32

Kelnar CJH, McKinnell C, Walker M, Morris KD, Wallace WHB, Saunders PTK, Fraser HM and Sharpe RM (2002) Testicular changes during infantile 'quiescence' in the marmoset and their gonadotrophin dependence: a model for investigating susceptibility of the prepubertal human testis to cancer therapy? Human Reproduction $\mathbf{1 7}$ 1367-1378

Kim IS (2001) Effects of exposure of lactating female rats to polychlorinated biphenyls (PCBs) on testis weight, sperm production and Sertoli cell numbers in the adult male offspring Journal of Veterinary Medical Science 63 5-9

Kliesch S, Behre HM, Hertle L and Bergmann M (1998) Alteration of Sertoli cell differentiation in the presence of carcinoma in situ in human testes Journal of Urology 160 1894-1898

Laslett AL, Li LH, Jester WF, Jr and Orth JM (2000) Thyroid hormone downregulates neural cell adhesion molecule expression and affects attachment of gonocytes in Sertoli cell-gonocyte co-cultures Endocrinology 141 1633-1641

Lenz S, Giwercman A, Elsborg A, Cohr KH, Jelnes JE, Carlsen E and Skakkeabek NE (1993) Ultrasonic testicular texture and size in 444 men from the genral population: correlation to semen quality European Urology 24 231-238

Li L-H, Jester WF, Jr, Laslett AL and Orth JM (2000) A single dose of Di-(2ethylhexyl) phthalate in neonatal rats alters gonocytes, reduces Sertoli cell proliferation and decreases cyclin D2 expression Toxicology and Applied Pharmacology 166 222-229

McCoard SA, Lunstra DD, Wise TH and Ford JJ (2001) Specific staining of Sertoli cell nuclei and evaluation of Sertoli cell number and proliferative activity in Meishan and White Composite boars during the neonatal period Biology of Reproduction 64 689-695

Mackay S (2000) Gonadal development in mammals at the cellular and molecular levels International Review of Cytology $20047-99$

McKinnell C, Saunders PTK, Fraser HM, Kelnar CJH, Kivlin C, Morris KD and Sharpe RM (2001) Comparison of androgen receptor and oestrogen receptor $\beta$ immunoexpression in the testes of the common marmoset (Callithrix jacchus) from birth to adulthood: low androgen receptor immunoexpression in Sertoli cells during the neonatal increase in testosterone concentrations Reproduction 122 419-429

McLaren TT, Foster PMD and Sharpe RM (1993) Effect of age on seminiferous tubule protein secretion and the adverse effects of testicular toxicants in the rat International Journal of Andrology 16 370379 
Mann DR, Akinbami MA, Wallen K, Gould KG, Groome NP, Swanston IA, McNeilly AS and Fraser HM (1997) Inhibin-B in the male Rhesus monkey: impact of neonatal gonadotropin-releasing hormone antagonist treatment and sexual development Journal of Clinical Endocrinology and Metabolism 82 1928-1933

Marshall GR and Plant TM (1996) Puberty occurring either spontaneously or induced precociously in rhesus monkey (Macaca mulatta) is associated with a marked proliferation of Sertoli cells Biology of Reproduction $\mathbf{5 4}$ 1192-1199

Maymon BB-S, Paz G, Elliott DJ, Hammel I, Kleiman SE, Yogev L, Hauser R, Botchan A and Yavetz H (2000) Maturation phenotype of Sertoli cells in testicular biopsies of azoospermic men Human Reproduction 15 1537-1542

Maymon BB-S, Yogev L, Paz G, Kleiman SE, Schriber L, Botchan A, Hauser R and Yavetz H (2002) Sertoli cell maturation in men with azoospermia of different etiologies Fertility and Sterility 77 904-909

Meachem SJ, McLachlan RI, de Kretser DM, Robertson DM and Wreford NG (1996) Neonatal exposure of rats to recombinant follicle-stimulating hormone increases adult Sertoli and spermatogenic cell numbers Biology of Reproduction $\mathbf{5 4}$ 36-44

Means AR, Fakunding JL, Huckins C, Tindall DJ and Vitale R (1976) Folliclestimulating hormone, the Sertoli cell and spermatogenesis Recent Progress in Hormone Research 32 477-527

Mylchreest E, Cattley RC and Foster PMD (1998) Male reproductive tract malformations in rats following gestational and lactational exposure to Di(n-butyl) phthalate: an anti-androgenic mechanism? Toxicological Science 43 47-60

Nistal M, Paniagua R, Abaurrea MA and Santamaria L (1982) Hyperplasia and the immature appearance of Sertoli cells in primary testicular disorders Human Pathology 13 3-12

Nistal M, Riestra ML and Paniagua R (2002) Focal orchitis in undescended testes: discussion of pathogenetic mechanisms of tubular atrophy Archives of Pathology and Laboratory Medicine 126 6469

Orth JM and Jester WF (1995) NCAM mediates adhesion between gonocytes and Sertoli cells in co-cultures from testes of neonatal rats Journal of Andrology 16 389-399

Orth JM, Gunsalus GM and Lamperti AA (1988) Evidence from Sertoli cell-depleted rats indicates that spermatid numbers in adults depends on numbers of Sertoli cells produced during perinatal development Endocrinology 122 787-794

Orth JM, Jester WF, Li LH and Laslett AL (2000) Gonocyte-Sertoli cell interactions during development of the neonatal rodent testis Current Topics in Developmental Biology 50 103-124

Palmero S, Prati M, Bolla F and Fugassa E (1995) Tri-iodothyronine directly affects rat Sertoli cell proliferation and differentiation Journal of Endocrinology 145 355-362

Paniagua R, Martinez-Onsurbe P, Santamaria L, Saez FJ, Amat P and Nistal M (1990) Quantitative and ultrastructural alterations in the lamina propria and Sertoli cells in human cryptorchid testes International Journal of Andrology 13 470-487

Panno ML, Salerno M, Lanzino M, De Luca G, Maggiolini M, Straface SV, Prati M, Palmero S, Bolla E and Fugassa E (1995) Follow-up study on the effects of thyroid hormone administration on androgen metabolism of peripubertal rat Sertoli cells European Journal of Endocrinology 132 236-241

Pelliniemi LJ and Frojdman K (2001) Structural and reguatory macromolecules in sex differentiation of gonads Journal of Experimental Zoology 290 523-528

Pierik FH, Vreeburg JT, Stijnen T, de Jong FH and Weber RF (1998) Serum inhibin B as a marker of spermatogenesis Journal of Clinical Endocrinology and Metabolism 83 3110-3114

Pinart E, Sancho S, Briz MD, Bonet S, Garcia N and Badia E (2000) Ultrastructural study of the boar seminiferous epithelium: changes in cryptorchidism Journal of Morphology 244 190-202

Plant TM and Marshall GR (2001) The functional significance of FSH in spermatogenesis and the control of its secretion in male primates Endocrine Reviews 22 764-786
Rajpert-de Meyts E, Jorgensen N, Graem N, Muller J, Cate RL and Skakkebaek NE (1999) Expression of anti-Mullerian hormone during normal and pathological gonadal development: association with differentiation of Sertoli and granulosa cells Journal of Clinical Endocrinology and Metabolism 84 3836-3844

Ramaswamy S, Marshall GR, McNeilly AS and Plant TM (1999) Evidence that in a physiological setting Sertoli cell number is the major determinant of circulating concentrations of inhibin B in the adult male rhesus monkey (Macaca mulatta). Journal of Andrology 20 430434

Ramaswamy S, Plant TM and Marshall GR (2000) Pulsatile stimulation with recombinant single chain human luteinizing hormone elicits precocious Sertoli cell prolferation in the juvenile male rhesus monkey (Macaca mulatta). Biology of Reproduction 63 82-88

${ }^{*}$ Regadera J, Martinez-Garcia F, Paniagua R and Nistal M (1999) Androgen insensitivity syndrome: an immunohistochemical, ultrastructural and morphometric study Archives of Pathology and Laboratory Medicine $123225-234$

Regadera J, Martinez-Garcia F, Gonzalez-Peramatao P, Serrano A, Nistal M and Suarez-Quian C (2001) Androgen receptor expression in Sertoli cells as a function of seminiferous tubule maturation in the human cryptorchid testis Journal of Clinical Endocrinology and Metabolism 86 413-421

Rey R, Mebarki F, Forest MG, Mowszowicz I, Cate RL, Morel Y, Chaussain JL and Josso N (1994) Anti-mullerian hormone in children with androgen insensitivity Journal of Clinical Endocrinology and Metabolism 79 960964

Rey R, Belville C, Nihoul-Fekete C et al. (1999) Evaluation of gonadal function in 107 intersex patients by means of serum antimullerian hormone measurement Journal of Clinical Endocrinology and Metabolism 84 627-631

Rogatsch H, Jezek D, Hittmair A, Mikuz G and Feichtinger H (1996) Expression of vimentin, cytokeratin and desmin in Sertoli cells of human fetal, cryptorchid and tumour-adjacent testicular tissue Virchows Archives 427 497-502

Schlatt S, Loveland K and de Kretser DM (1996) Discriminative analysis of Sertoli and peritubular cells and their proliferation in vitro: evidence for FSH-mediated contact inhibition of Sertoli cell mitosis Biology of Reproduction $\mathbf{5 5}$ 227-235

Sharpe RM (1994) Regulation of spermatogenesis. In The Physiology of Reproduction 2nd Edn. pp 1363-1434 Eds E Knobil and JD Neill. Raven Press, New York

Sharpe RM (1999) Fetal/neonatal hormones and reproductive function of the male in adulthood. In Fetal Programming: Influences on Development and Disease in Later Life pp 187-194 Eds PMS O'Brien, T Wheeler and DJP Barker. Royal College of Obstetricians and Gynaecologists Press, London

Sharpe RM (2001) Hormones and testis development and the possible adverse effects of environmental chemicals Toxicology Letters 120221 232

Sharpe RM and Franks S (2002) Environment/lifestyle and human infertility - an inter-generational issue Nature Cell Biology 4 Supplement $133-$ 40

Sharpe RM and Skakkebaek NE Male reproductive disorders and the role of endocrine disruption: advances in understanding and identification of areas for future research Pure and Applied Chemistry (in press)

Sharpe RM, Millar MR and McKinnell C (1993) Relative roles of testosterone and the germ cell complement in determining stage-dependent changes in protein secretion by isolated rat seminiferous tubules International Journal of Andrology 16 71-81

Sharpe RM, Turner KJ, McKinnell C, Groome NP, Atanassova NN, Millar MR, Buchanan DL and Cooke PS (1999) Inhibin-B levels in plasma of the male rat from birth to adulthood: effect of experimental manipulation of Sertoli cell number Journal of Andrology 20 94-101

Sharpe RM, Walker M, Millar MR, Atanassova N, Morris K, McKinnell C, Saunders PT and Fraser HM (2000) Effect of neonatal gonadotrophinreleasing hormone antagonist administration on Sertoli cell number and 
testicular development in the marmoset: comparison with the rat Biology of Reproduction 62 1685-1693

Simorangkir DR, de Kretser DM and Wreford NG (1995) Increased numbers of Sertoli and germ cells in adult rat testes induced by synergistic action of transient neonatal hypothyroidism and neonatal hemicastration Journal of Reproduction and Fertility 104 207-213

${ }^{*}$ Skakkebaek NE, Rajpert-de Meyts E and Main KM (2001) Testicular dysgenesis syndrome: an increasingly common developmental disorder with environmental aspects Human Reproduction 16 972-978

Slegtenhorst-Eegdeman KE, de Rooij DG, Verhoef-Post M, van de Kant HJ, Bakker CE, Oostra BA, Grootegoed JA and Themmen AP (1998) Macroorchidism in FMR1 knockout mice is caused by increased Sertoli cell proliferation during testicular development Endocrinology 139156 162

Steger K, Rey R, Kliesch S, Louis F, Schleicher G and Bergmann M (1996) Immunohistochemical detection of immature Sertoli cell markers in testicular tissue of infertile adult men: a preliminary study International Journal of Andrology 19 122-128

Steger K, Rey R, Louis F, Kliesch S, Behre HM, Nieschlag E, Hoepffner W, Bailey D, Marks A and Bergmann M (1999) Reversion of the differentiated phenotype and maturation block in Sertoli cells in pathological human testis Human Reproduction 14 136-143

Storgaard L, Bonde JP, Ernst E, Spano M, Andersen CY, Frydenberg $M$ and Olsen J Is smoking during pregnancy the cause of the apparent decline in sperm counts? Epidemiology (in press)

Stosiek P, Kasper M and Karsten U (1990) Expression of cytokeratins 8 and 18 in human Sertoli cells of immature and atrophic seminiferous tubules Differentiation 43 66-70

Suarez-Quian CA, Martinez-Garcia F, Nistal M and Regadera J (1999) Androgen receptor distribution in adult human testis Journal of Clinical Endocrinology and Metabolism 84 350-358
Turner KJ, Macpherson S, Millar MR, McNeilly AS, Williams K, Cranfield M, Groome NP, Sharpe RM, Fraser HM and Saunders PTK (2002) Development and validation of a new monoclonal antibody to mammalian aromatase Journal of Endocrinology 172 21-30

Ulisse S, Jannini EA, Carosa E, Piersanti D, Graziano FM and D'Armiento M (1994) Inhibition of aromatase activity in rat Sertoli cells by thyroid hormone Journal of Endocrinology 140 431-436

Van Haaster LH, de Jong FH, Docter R and de Rooij DG (1993) High neonatal triiodothyronine levels reduce the period of Sertoli cell proliferation and accelerate tubular lumen formation in the rat testis, and increase serum inhibin levels Endocrinology 133 755-760

Wang NP, de Kretser DM and Wreford NG (1989) Determination of Sertoli cell numbers in the developing rat testis by stereological methods International Journal of Andrology 12 58-64

Williams K, McKinnell C, Saunders PTK, Walker M, Fisher JS, Turner KJ, Atanassova N and Sharpe RM (2001) Neonatal exposure to potent and environmental oestrogens and abnormalities of the male reproductive system in the rat: evidence for importance of the androgen:oestrogen balance and assessment of the relevance to man Human Reproduction Update $7236-247$

Winters SJ and Plant TM (1999) Partial characterization of circulating inhibin-B and pro-alphaC: during development in the male rhesus monkey Endocrinology 140 5497-5504

Yomogida K, Ohtani H, Harigae H, Ito E, Nishimune Y, Engel JD and Yamamoto M (1994) Developmental stage- and spermatogenic cyclespecific expression of transcription factor GATA- 1 in mouse Sertoli cells Development 120 1759-1766

Young J, Rey R, Couzinet B, Chanson P, Josso N and Schaison G (1999) Antimullerian hormone in patients with hypogonadotropic hypogonadism Journal of Clinical Endocrinology and Metabolism $\mathbf{8 4}$ 2696-2699 